$1-1-2004$

\title{
Agroforestry, elephants, and tigers: Balancing conservation theory and practice in human-dominated landscapes of Southeast Asia
}

Philip J. Nyhus

Colby College, pjnyhus@colby.edu

\author{
R L. Tilson
}

Follow this and additional works at: https://digitalcommons.colby.edu/faculty_scholarship

Part of the Biodiversity Commons, Forest Management Commons, International and Area Studies Commons, Nature and Society Relations Commons, and the Zoology Commons

\section{Recommended Citation}

Nyhus, Philip J. and Tilson, R L., "Agroforestry, elephants, and tigers: Balancing conservation theory and practice in human-dominated landscapes of Southeast Asia" (2004). Faculty Scholarship. 49.

https://digitalcommons.colby.edu/faculty_scholarship/49 


\title{
Agroforestry, elephants, and tigers: balancing conservation theory and practice in human-dominated landscapes of Southeast Asia
}

\author{
Philip Nyhus $^{\mathrm{a}, *}$, Ronald Tilson ${ }^{\mathrm{b}}$ \\ ${ }^{\text {a }}$ Department of Earth and Environment, Franklin and Marshall College, Lancaster, PA 17604-3003, USA

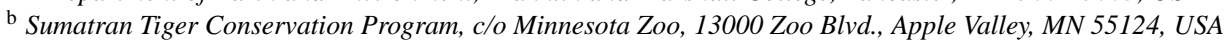

\begin{abstract}
Large mammal populations theoretically are best conserved in landscapes where large protected areas are surrounded by buffer zones, connected by corridors, and integrated into a greater ecosystem. Multi-use buffer zones, including those containing complex agroforestry systems, are promoted as one strategy to provide both economic benefits to people and conservation benefits to wildlife. We use the island of Sumatra, Indonesia to explore the benefits and limitations of this strategy. We conclude that conservation benefits are accrued by expanding the habitat available for large mammals but more attention needs to be focused on how to reduce and respond to human-wildlife conflict that is likely to occur in these multiple use areas. Agroforestry systems are likely to play an increasingly valuable role in the conservation of large mammalian species. We believe this value can be increased still further if the agroforestry community decides to assume a leadership role in addressing the issue of human-wildlife conflict, which is fast becoming a central threat to the survival of many large endangered species like tigers and elephants. Both people and wildlife can benefit enormously if appropriate methods are developed to more rigorously define the distribution and frequency of conflict between tigers and elephants with people along the edge of protected areas. Sharp forest-agriculture boundaries may reduce tiger-human conflicts, but not elephant-human conflict according to the data we currently have.
\end{abstract}

(C) 2004 Elsevier B.V. All rights reserved.

Keywords: Agroforestry; Conflict; Conservation; Elephants; Sumatra; Tiger

\section{Introduction}

Tropical forest conversion and modification continue at alarming rates globally and particularly in Southeast Asia (Brooks et al., 1999; WRI, 2000). The resulting habitat loss, degradation, and fragmentation are serious threats to the conservation of biological diversity (Harris and Silva-Lopez, 1992). Rapid human population growth in much of the tropics has resulted in many protected areas and biodiversity "hot spots" becoming habitat islands surrounded by a matrix of

\footnotetext{
* Corresponding author.

E-mail address: philip.nyhus@fandm.edu (P. Nyhus).
}

human-dominated landscapes that constrain efforts to conserve biological diversity (Janzen, 1983; Wilcox and Murphy, 1985; Harris and Silva-Lopez, 1992; Cincotta et al., 2000).

Examples from every continent and current conservation theory suggest that strictly protected areas are needed to enable a full complement of a region's biological diversity to persist over the long term (Kramer et al., 1997; Noss et al., 1999). To maintain the integrity of the fauna and flora within these core protected areas buffer zones are frequently established to reduce the impact of people on the biodiversity inside reserves (Shafer, 1990; Sayer, 1991; Groom et al., 1999). Buffer zones extend the available habitat 
for plants and animals (extension buffering) and provide resources and services to people (socio-buffering) (MacKinnon et al., 1986). One important challenge is to identify land use systems that can simultaneously fulfill both roles (Salafsky, 1993) while minimizing the potential for conflict among wildlife and stakeholders using this resource.

In the tropics, and particularly in Southeast Asia, buffer zones that incorporate agroforestry systems provide one such approach (Siebert, 1989; Michon and de Foresta, 1990; Salafsky, 1993; Van Schaik and Terborgh, 1993; Potter and Lee, 1998; Vandermeer et al., 1998; Johns, 1999). Agroforestry systems are characterized by generally higher biological diversity compared to surrounding agricultural landscapes and monoculture cultivation but generally lower biological diversity compared to primary forests (Michon and de Foresta, 1990; Pimentel et al., 1992; Thiollay, 1995; Vandermeer et al., 1998). Overall, they contribute to considerable plant, invertebrate, and bird diversity (Thiollay, 1995; Lawton et al., 1998; Vandermeer et al., 1998). Plantations, production forests, and other managed forest systems offer additional opportunities to expand habitat available for biological diversity beyond the boundaries of core protected areas (MacKinnon et al., 1986; Sayer, 1991).

Agroforestry systems also provide significant economic benefits to people (Michon and de Foresta, 1990; Nair, 1991; Wojtkowski, 1993; Brookfield and Padoch, 1994). In Indonesia, for example, smallholders grow stands of trees as components of their diverse farming systems (Potter and Lee, 1998) and help to make the country the world's second largest producer of natural rubber (about three-quarters produced by smallholders), the world's third largest produce of coffee (95\% of production by smallholders) and the fourth largest producer of cocoa (Sunderlin and Resosudarmo, 1996). More than 200,000 people are employed by the rattan industry alone (FAO, 1998).

The issue we address in this paper is how agroforestry systems adjacent to core wildlife habitat may have significant conservation value by extending available habitat for large mammals and serving as wildlife corridors but may also increase the risk of conflict with people using these same areas. Tigers (Panthera tigris) and elephants (Elephas maximus) are a principal source of conflict in much of Asia (McDougal, 1987; Sukumar and Gadgil, 1988; Nowell and
Jackson, 1996) and the same is true in Sumatra (Santiapillai and Ramono, 1993; Tilson and Nyhus, 1998). Recent history has shown that wildlife conflict with humans can increase as existing habitat becomes progressively fragmented and the pressure of human encroachment becomes more severe (McNeely, 1978; Seidensticker, 1984; McDougal, 1987; Sukumar, 1989; Nowell and Jackson, 1996). We are concerned that the potential linkages among agroforestry systems, wildlife conservation, and human-wildlife conflict have not been adequately considered.

We use our experiences in Lampung Province, Sumatra, Indonesia, as a case study to highlight this challenge. Since 1995, we have collected data to evaluate the extent and distribution of tiger and elephant conflict at Way Kambas National Park (Nyhus et al., 2000; Nyhus and Tilson, 2004) and are now extending these observation to other areas of Sumatra as part of the Sumatran Tiger Project (Tilson et al., 1996, 1997, 2001). We discuss the implications of our observations for the development and management of both agroforestry systems and conservation of these mega-vertebrates.

\section{Sumatra and Lampung Province}

The island of Sumatra (Fig. 1) has significant biological diversity (Whitten et al., 1987; MSPE, 1992). Covering $474,000 \mathrm{~km}^{2}$ the island is also home to 45 million people (BPS, 1999). Today, some of Indonesia's fastest deforestation rates occur on the island and only one-third of its once abundant forests remain (FWI/GFW, 2002). Holmes (2002) estimates that all lowland forests outside of protected areas will likely disappear by 2005 .

Sumatra's protected area system encompasses close to one-fifth of its land area (MacAndrews, 1998) and is administered by the Indonesian Ministry of Forestry. It is characterized by many small reserves and few large reserves. Of its 231 protected areas, $75 \%$ are less than $300 \mathrm{~km}^{2}$ in size. Protection forests account for over half of this total area and over half the total number of reserves, but many are degraded and harvesting of natural resources by local villagers is common. The only strictly protected areas of significance are the island's six National Parks (Taman Nasional) (Table 1). 


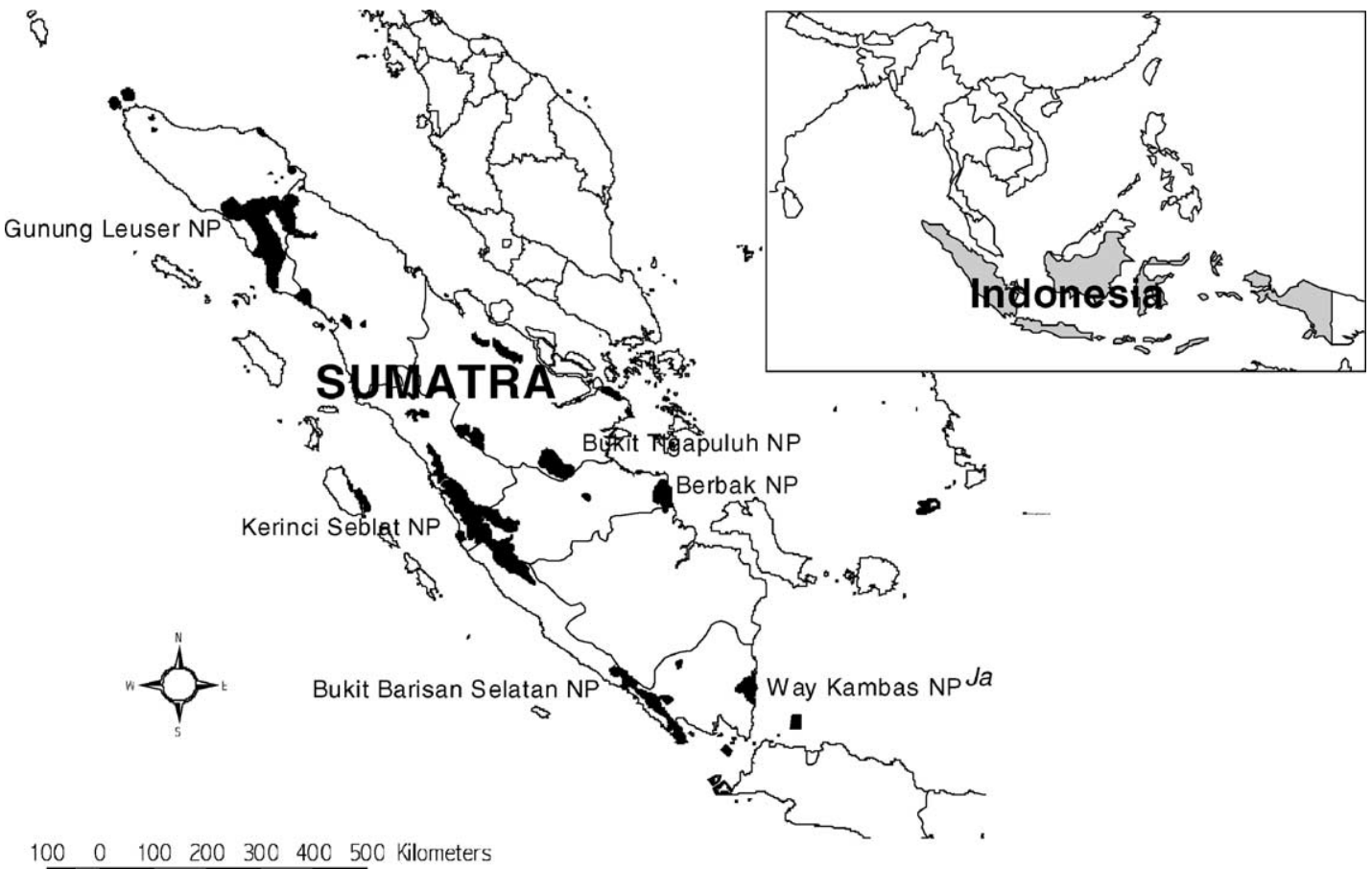

Fig. 1. Map of Sumatra showing the location of the principle protected areas.

Table 1

Number and size of protected areas in Sumatra by official Indonesian categories

\begin{tabular}{lrcrr}
\hline Category & $N$ & Total $N(\%)$ & Sum area & Total area $(\%)$ \\
\hline Grand forest park & 1 & 0.4 & 222 & 0.3 \\
Hunting park & 4 & 1.7 & 1149 & 1.4 \\
Recreation park $_{\text {National Park }}^{\mathrm{a}}$ & 5 & 2.2 & 223 & 0.3 \\
Nature reserve & 7 & 3.0 & 31366 & 38.0 \\
Game reserve & 9 & 5.6 & 567 & 0.7 \\
Protection forest & 13 & 83.1 & 43689 & 6.4 \\
Total & 192 & 100.0 & 82478 & 53.0 \\
\end{tabular}

Source: (IUCN, 1998).

a Includes Siberut National Park $\left(1905 \mathrm{~km}^{2}\right)$ located in the Mentawai islands off of mainland Sumatra.

Lampung, the most southerly of Sumatra's eight provinces, has some of the fastest human population growth rates and densities in Sumatra (BPS, 1999) because it was one of the first areas targeted by the government's transmigration policies (Hardjono, 1977). Two national parks, Bukit Barisan Selatan in the west and Way Kambas in the east, are located in this province.

\section{Agroforestry in Sumatra}

Agroforestry systems are a prominent component of farming systems in Sumatra. Depending on the region, on average between 20 and $60 \%$ of the cultivated land area is occupied by agroforests used for cash income and smallholder gardens of specialized crops (Godoy and Bennett, 1989; Siebert, 1989; Michon and 
de Foresta, 1990; Barlow and Tomich, 1991; Thiollay, 1995). Rubber forests and complex agroforests characterized by fruit trees and other useful species are particularly common (Padoch and Peters, 1993).

The prominence of agroforestry systems has significance for Sumatra's conservation areas. The Indonesian Ministry of Forestry under the Suharto government initiated social forestry schemes (Hutan kemasyarakatan) encouraging smallholders to plant trees on production forest land to create buffer zones around protection forests. Approximately $70 \%$ of trees in these schemes are for timber while the remainder are fruit trees which smallholders may cultivate and utilize but not cut (Potter and Lee, 1998). Similar schemes have been promoted among inhabitants living near Sumatra's largest protected areas. Near Kerinci Seblat National Park, for example, the maintenance of a buffer zone has been an important management policy. On the park's border, complex agroforestry systems include cinnamon, coffee, legume, fruit, and timber trees are common (Potter and Lee, 1998). In some areas, these trees are being cultivated within the park (Pagiola, 2001).

\section{Tigers, elephants, and conflict in Sumatra}

Tigers and elephants often share the same habitat, and because of their broad distribution across Asia, any conservation program for these animals will also offer protection for the many other species that share their habitats (Santiapillai and Jackson, 1990; Norchi and Bolze, 1995; Nowell and Jackson, 1996). In Sumatra, these two species once numbered in the tens of thousands and were found across the island, but today are restricted to a handful of isolated protected areas (Santiapillai and Jackson, 1990; Tilson et al., 1994b) (Table 2). An estimated 500 Sumatran tigers are found in all eight provinces of Sumatra, but their distribution is spread over some 26 disjunct populations (Tilson et al., 1994b). Elephants are estimated to number between 2800 and 4800 and their populations are highly fragmented (Tilson et al., 1994a). The decline of these populations and their increasingly isolated distribution is directly related to the rapid human population growth on the island and the large-scale loss and degradation of optimal habitat (Tilson et al., 1994a,b, 2001). Populations of tigers and elephants were historically high in Lampung Province and persist in core protected areas and several adjacent forest fragments (Tilson et al., 1994a, 2001).

Both animals play important ecological roles. Large predators play a pivotal "top-down" regulatory role in helping to maintain biological diversity in terrestrial communities through trophic cascades and preferential feeding on prey species (Soulé and Terborgh, 1999). In Sumatra, tigers are thought to regulate populations of pig (Sus scrofa) and large ungulates (Santiapillai and Ramono, 1985; Seidensticker, 1986). Where tiger are missing, these prey species often become

Table 2

Comparison of wild tiger and elephant populations and distributions in Sumatra

\begin{tabular}{lll}
\hline & Sumatran tiger (Panthera tigris sumatrae) & Sumatran elephant (Elephas maximus sumatranus) \\
\hline Historic distribution & Continuously distributed across island ${ }^{\mathrm{a}}$ & Continuously distributed across island \\
Estimated wild population & $500^{\mathrm{a}}$ & $2800-4800^{\mathrm{b}}$ \\
Estimated wild population by forest status & \\
National parks & $400^{\mathrm{a}}$ & $963-1173^{\mathrm{b}}$ \\
Game reserves & n.a. & $710-860^{\mathrm{b}}$ \\
Protection forests & $100^{\mathrm{a}}$ & $130-180^{\mathrm{b}}$ \\
Production forests & n.a. & $1890-2320^{\mathrm{b}}$ \\
Population in Way Kambas & $25-40^{\mathrm{c}}$ & $100-300^{\mathrm{b}}$ \\
No. populations & $26^{\mathrm{a}}$ & $47^{\mathrm{b}}$ \\
IUCN Status & Critically endangered & Endangered $^{\mathrm{d}}$ \\
\hline
\end{tabular}

\footnotetext{
${ }^{\text {a }}$ Tilson et al. (1994b).

b Tilson et al. (1994a).

${ }^{\mathrm{c}}$ Franklin et al. (1999).

${ }^{d}$ Nowell and Jackson (1996).

e Santiapillai and Jackson (1990).
} 
agricultural pests. Studies of Asian elephants have documented their important role as agents of seed dispersal and disturbance in influencing forest dynamics (McKay, 1973; Santiapillai and Suprahman, 1986; Sukumar, 1989).

\subsection{Tiger conflict}

To evaluate tiger conflict, we methodically collected more than 200 Indonesian- and English-language reports, documents, press reports, and other information about tiger-human conflicts in Sumatra for the past 20 years (Nyhus and Tilson, 2004). Cases were coded into categories for location of attacks, information about human and livestock victims, and details about the tigers and events that followed tiger attacks. We also investigated several incidents in person where tigers were injuring or killing livestock or people (STP, 1997, 1998; Tilson and Nyhus, 1998).

On average, at least four people were killed per year across the island of Sumatra between 1978 and 1997 (Nyhus and Tilson, 2004). Out of 146 people reportedly killed and 30 people injured over this period, information on where these attacks occurred was available only for a subset of cases. In this subset, tiger conflict was lower in undisturbed forests and protected areas or highly disturbed areas and highest in moderately disturbed areas where there was a high probability of overlap between people and tigers (Table 3). Reports of tiger conflicts have been reported in buffer zones adjacent to Gunung Leuser, Bukit Barisan Selatan, Berbak, Kerinci, and Bukit Tigapuluh national parks and in virtually every province (KMNKLH, 1985; Sinaga, 1995; SBKDSA-Jambi, 1997). These observations suggest that the probability of future tiger-human conflicts in Sumatra are considerable in protection forests, degraded forests, industrial forests, agroforestry areas, and other multiple use areas on the edges of protected areas where tigers and humans share resources (Tilson and Nyhus, 1998). Examples of activities carried out by villagers attacked by tigers include gathering rubber, working in their fields and gardens (ladang), collecting cinnamon, or collecting wood and non-timber forest products.

A comparison of two national parks in Lampung Province help to illustrate why this might be the case. Bukit Barisan Selatan National Park is surrounded by many production forests, protection forests, and other
Table 3

Characteristics of attacks by tigers on people in Sumatra (1978-1997)

\begin{tabular}{lcc}
\hline Category & \multicolumn{2}{l}{ Victims } \\
\cline { 2 - 3 } & $n$ & $\%$ \\
\hline Victim's activity $(n=66)$ & & \\
$\quad$ Working in fields & 34 & 51.5 \\
In forest & 22 & 33.3 \\
Near homes & 6 & 9.1 \\
On roads & 4 & 6.1 \\
Habitat type $(n=57)$ & & \\
Low disturbance & 13 & 22.8 \\
Intermediate disturbance & 29 & 50.9 \\
High disturbance & 15 & 26.3 \\
Location of attack $(n=66)$ & & \\
$\quad$ Villages & 4 & 25.8 \\
Agricultural fields & 17 & 21.2 \\
Forest edge & 31 & \\
Primarily forested areas & 14 &
\end{tabular}

Source: (Nyhus and Tilson, 2004).

forested habitat that create both a buffer and corridors linking different habitat patches (Tilson et al., 2001). During early 1997, three people were killed and three others injured in forests near this park in logged over forest (Register 34) where coffee and other agricultural commodities were abundant and a major government-sponsored regreening program was underway (STP, 1997). In April 1998, a child was attacked by a tiger while sleeping in a hut near recently cleared forest land adjacent to the park (STP, 1998). In both cases, prey species were available but human activity in these areas was high.

In contrast, no buffer zone or significant forest patches suitable for wildlife are found adjacent to Way Kambas National park (Ministry of Forestry, 1995; Nyhus et al., 1999). The park is bordered by the Java Sea on one side, rivers on two sides, and on the fourth side, the edge of the park and the cultivated land directly abut each other. Despite a known tiger population of as many as 40 tigers and an estimated density of 4.3 tigers per $100 \mathrm{~km}^{2}$ (Franklin et al., 1999), only one death by tigers has been reported in the last 20 years, and this occurred just inside the park when a farmer collecting grass was killed by a tiger in 1995 (Tilson and Nyhus, 1998; Nyhus et al., 1999). This lack of conflict is even more interesting considering that 90,000 people live in 27 villages immediately bordering the park. 
These two examples highlight how conflict with tigers may be higher in areas where the probability of people overlapping with tigers and habitat degradation is high compared to habitat within the boundaries of core protected areas. We do not have sufficient data to say that conflict will necessarily be higher in agroforestry systems over other multiple use areas, but we feel confident in hypothesizing that the prevalence of these systems in and near tiger habitat in Sumatra makes them potential hot spots for future conflict. Recent history bears out why such concerns are warranted. Extermination of problem tigers as core wildlife habitat diminished played an important role in the demise and eventual extinction of the Javan tiger in the 1970s (Hoogerwerf, 1970; Seidensticker, 1987) and the likely extinction in the wild of the South China tiger (Tilson et al., 2004).

Our observations from Sumatra are supported by experiences in other areas of the world. In a survey of the literature and global analysis of existing data on population extinction of 10 species of large carnivores, Woodroffe and Ginsberg (1998) found that conflict with people on reserve borders is the major cause of mortality of large carnivores. They conclude that priority should be given to measures that seek to mitigate carnivore persecution on reserve borders or in buffer zones. In Nepal, at least 14 people were killed in 1998-1999 by tigers, with over half of these occurring in buffer zones outside two national parks (McDougal, 1999). Numerous other examples of tiger conflict in multiple use areas exist in the literature (McDougal, 1987; Nowell and Jackson, 1996; Helalsiddiqui, 1998) as do examples with other carnivores (Nowell and Jackson, 1996). To cite one example, between 1978 and 1991, 78\% of all incidents of Asiatic lion (Panthera leo persica) and human conflict in Gir Forest, India, occurred on private lands outside the main forest reserve (Saberwal et al., 1995).

\subsubsection{Elephant conflict}

Few data exist on elephant conflict in Sumatra but it is widely recognized as a significant problem (Santiapillai and Jackson, 1990; Santiapillai and Ramono, 1993; Tilson et al., 1994a). Press reports frequently describe incidents of crop-raiding and more than 500 of these elephants have been captured and translocated to protected areas or elephant training centers across Sumatra over the last two decades (Lair, 1997).

Forest cover and availability of food and water positively influence the movement of elephants and wide buffers containing Imperata grasslands or other vegetation not suitable for food or cover tend to inhibit the movement of elephants (McKay, 1973; Seidensticker, 1984; Sukumar, 1989). These patterns were confirmed in a survey of villages surrounding Way Kambas by Nyhus et al. (2000). Crop-raiding was highest where secondary growth forests immediately abutted village fields and lower where grasslands and wetlands provided buffers between forest and fields. Unlike tigers, elephants are a frequent source of conflict in villages near the park. Elephant crop-raiding causes significant economic damage and villagers are forced to spend long hours guarding their fields. Between 1984 and 1996, at least 15 people were reportedly killed and 9 injured by elephants near the park's boundary (Nyhus et al., 2000).

As elephant habitat continues to decline around core elephant habitats, it is reasonable to assume that areas outside protected areas like Way Kambas are likely to continue to be conflict hot spots. Unlike tigers, elephant conflict hot spots may actually be higher in agricultural areas, where high-protein foods are accessible (Sukumar, 1989). Nevertheless, even a lone bull elephant has the potential to cause problems (Sukumar, 1989) and abundant examples in Sumatra already show that conflict can and does occur in multiple use buffer zones and agroforestry areas around elephant protected areas (Santiapillai, 1990).

\section{Balancing wildlife conflict in agroforestry systems}

Landscapes outside strict protected areas are gaining increasing attention from wildlife researchers for their conservation value. Given adequate availability of prey and low poaching pressure, tigers have a high probability of persistence. Karanth and Stith (1999) argue that identifying, protecting, maintaining, and monitoring prey-rich habitat patches, some as small as $300 \mathrm{~km}^{2}$ and set in a larger landscape matrix with multiple uses, should be central to tiger conservation and recovery efforts in Asia. Others argue that existing protected areas are already too small to maintain 
viable populations of many large animals, and only by extending the habitat beyond park boundaries can viable tiger and large carnivore populations be maintained over a long period of time (Santiapillai and Jackson, 1990; Nowell and Jackson, 1996; Dinerstein et al., 1997; Seidensticker, 1997; Dinerstein et al., 1999; Seidensticker et al., 1999).

As an important land use type in Sumatra, the value of agroforestry systems for integrating biological conservation and economic development goals is high. What is less clear is what needs to be done to address the problem of conflict between large mammals and people in these and other similar areas. Historically, the problem of human-wildlife conflict has fallen under the aegis of wildlife conservation authorities. However, their jurisdiction often ends at the park's boundary, and when tigers and elephants cross this boundary, the dilemma of who is responsible for dealing with wildlife conflict can be uncertain. Solutions are difficult to develop because there is no professional discipline which embraces the subject (Nowell and Jackson, 1996). As a result, when livestock are killed by tigers, elephant raid crops, or people are injured or killed, local people often take matters into their own hands and kill the offending animals (Nowell and Jackson, 1996; Tilson and Nyhus, 1998). Ultimately, both people and wildlife suffer the consequences where conflict is unresolved.

Several steps could be taken to better understand and address this issue. First, there is a dearth of rigorous field data to test these observations and hypotheses. We do not even know with any certainty where tigers and elephants are still distributed in Sumatra, how many remain, or how their populations are increasing or declining (Tilson et al., 1994a,b). This information is urgently needed. Several ecological indicators may also be useful monitoring tools to identify potential conflict hot spots. For tigers, the presence of prey species is an important indicator of habitat health (Karanth and Stith, 1999). Where prey density is low, either because of hunting or habitat degradation, tigers may be more likely to kill livestock (McDougal, 1987; Nowell and Jackson, 1996). For elephants, herd size and availability of food and water (Sukumar, 1989) may be important ecological indicators.

Second, there is a need to encourage dialogue among agencies and organizations focused on conservation within protected areas with those managing and promoting agroforestry and other multiple use land use systems adjacent to these protected areas. Considering how to reduce human-wildlife conflict in the early stages of planning may better support the development of the financial and human resources required to work with local communities to address conflicts when they occur. To date, there has been relatively little common work on this issue between researchers involved with wildlife biology and agroforestry. The agroforestry community has the potential to play a leading role in developing theoretical analyses and carrying out collaborative field research with wildlife conservationists to explore how to reduce tiger and elephant conflict, and thus contribute to the conservation of these species. Examples of questions that could benefit from such cross-disciplinary research include the following:

1. How might consideration of the potential for human-wildlife conflict influence the planning, development, and management of buffer zones, Integrated Conservation and Development Projects (ICDPs), and corridors connecting adjacent protected areas in the human-dominated landscapes of Southeast Asia?

2. How do different buffering strategies promote or inhibit conflict between humans and large mammals, including tigers, elephants, wild pigs, and primates?

3. How do different buffering strategies affect the conservation of different species assemblages (e.g. invertebrates, birds, amphibians, and large mammals) in the context of human activities and what are the benefits (e.g. greater habitat area) and risks (e.g. greater conflict) associated with different land use choices?

Third, where conflict occurs, authorities must be ready to respond to remove the problem animal(s) by translocation, transfer to captive facilities, or with lethal means in extreme circumstances. Isolated tiger and elephant populations, particularly those in multiple use areas distant from major protected areas that are too small to be demographically or genetically viable over the long term, may need to be moved proactively to larger protected habitat areas. In Sumatra, there are already successful precedents for doing this with both tigers and elephants. Small-scale compensation efforts have also been implemented in Sumatra. 
Globally, well-run compensation programs have been shown to be potentially effective strategies for reducing animosity among cultivators and ranchers when large mammals do leave protected areas and destroy property. Compensation efforts can also be used to encourage the adoption of livestock husbandry practices that reduce conflict (Nyhus et al., 2003). Strategies for efficiently and effectively distributing such programs in remote areas of Sumatra would be valuable.

In addition to habitat loss and prey depletion, stochastic events can pose significant risks to wildlife populations. For example, fires represent a serious threat to large mammals and increase the probability of conflict. During the extended drought and fires that followed an extreme El Niño Southern Oscillation (ENSO) event in 1997 and 1998 an estimated $13,000-15,000 \mathrm{~km}^{2}$ of forest burned in Sumatra (Levine et al., 1999). In just one example, tigers and elephants were reported leaving burning areas near Berbak National Park, where one person was reported killed by a tiger while attempting to scare away a group of elephants. Without long term consideration of how the habitat matrix surrounding existing protected areas may exacerbate such fires or the results of these fires on wildlife, these disasters are likely to compound the already dire conservation situation for the island's remaining large mammals.

\section{Conclusion}

Theory and models of large mammal conservation are increasingly stressing the integration of core protected areas within a larger human-dominated landscape matrix, where core habitats are surrounded by buffers and linked with habitat corridors (Soulé and Terborgh, 1999). Given the right pre-requisites, buffer zones and corridors can have tremendous benefits for both conservation of large mammals like tigers and economic development (Dinerstein, 1999; Dinerstein et al., 1999). The social and political reality of many landscapes in Asia, however, suggest greater attention needs to be given to the constrains of high human population densities, highly fragmented habitats, and intensive land use near core protected areas that may constrain efforts to develop these "ideal" conservation scenarios (Tilson et al., 2001). The growing calls among biologists to emphasize landscape-level conservation that transcends core protected areas (Dinerstein et al., 1997; Seidensticker et al., 1999; Soulé and Terborgh, 1999) requires the attention of specialists and managers who are involved with the management of these resources and who will ultimately have to address the consequences of these policies.

Buffer zones in Asia are one area where further development of these models is needed. The issue of human-wildlife conflict is complex, and its management ultimately requires site-specific information. We need a better understanding of the different conservation benefits and human-wildlife conflict risks among a range of systems, including monoculture, multi-species, and degraded or secondary growth ecosystems. In Southeast Asia, the large number of institutions and individuals involved directly or indirectly with agroforestry, and the uniqueness of these systems as areas where humans and wildlife overlap could provide an ideal context for human-wildlife conflict research and policy.

Areas outside core protected habitats may play an increasingly important role in the conservation of wide-ranging mammalian species like tigers and elephants. The value of agroforestry systems for promoting biological diversity is already well established. We believe this value can be increased still further if the agroforestry and agricultural community decides to assume a leadership role in addressing the issue of human-wildlife conflict outside of traditional wildlife conservation areas, which is fast becoming one of the most central threats to the survival of many large animals, particularly large endangered species like tigers and elephants.

Both people and wildlife will benefit enormously if appropriate methods are developed to more rigorously define and reduce the distribution and frequency of conflict between tigers and elephants with people along the edge of protected areas.

\section{Acknowledgements}

We are grateful to the Indonesian Institute of Sciences, the Ministry of Forestry's Directorate of Forest Protection and Nature Conservation, the director and staff of Way Kambas National Park, staff and students of the University of Lampung, and staff of the 
Sumatran Tiger Conservation Program. We especially acknowledge the assistance of local community leaders and informants. This study was funded primarily by the Save The Tiger Fund, a special project of the National Fish and Wildlife Foundation in partnership with ExxonMobil, administered through the Minnesota Zoo Foundation. Additional support was received from The Rhinoceros and Tiger Conservation Fund of the US Fish and Wildlife Service and the US National Security and Education Program (to $\mathrm{PN})$. Other conservation partners of this component of the Sumatran Tiger Conservation Program include the The Tiger Foundation (Canada), the Sumatran Tiger Trust (UK), Discovery Channel (Singapore) and Dreamworld (Australia). Thomas Tomich and Meine van Noordwijk provided useful comments on an earlier version of this manuscript.

\section{References}

Barlow, C., Tomich, T., 1991. Indonesian agricultural development: the awkward case of smallholder tree crops. Bull. Indonesian Econ. Stud. 27, 29-53.

BPS, 1999. Unpublished data. Biro Pusat Statistik, Jakarta.

Brookfield, H., Padoch, C., 1994. Appreciating agrodiversity: a look at the dynamics and diversity of indigenous farming practices. Environment 36, 6.

Brooks, T.M., Pimm, S.L., Kapos, V., Ravilious, C., 1999. Threat from deforestation to montane and lowland birds and mammals in insular Southeast Asia. J. Anim. Ecol. 68, 1061-1078.

Cincotta, R.P., Wisnewski, J., Engelman, R., 2000. Human population in the biodiversity hotspots. Nature 404, 990-992.

Dinerstein, E., 1999. Pre-requisites for adapting the Chitwan model to other Tiger Conservation Units in Asia. In: Seidensticker, J., Christie, S., Jackson, P. (Eds.), Riding the Tiger: Tiger Conservation in Human-dominated Landscapes. Cambridge University Press, Cambridge, pp. 332-333.

Dinerstein, E., Rijal, A., Bookbinder, M., Kattel, B., Rajuria, A., 1999. Tigers as neighbors: efforts to promote local guardianship of endangered species in lowland Nepal. In: Seidensticker, J., Christie, S., Jackson, P. (Eds.), Riding the Tiger: Tiger Conservation in Human-dominated Landscapes. Cambridge University Press, Cambridge, pp. 316-333.

Dinerstein, E., Wikramanayake, E., Robinson, J., Karanth, U., Rabinowitz, A., Olson, D., Mathew, T., Hedao, P., Connor, M., Hemley, G., Bolze, D., 1997. A Framework for Identifying High Priority Areas and Actions for the Conservation of Tigers in the Wild. World Wildlife Fund-US and Wildlife Conservation Society, Washington, DC.

FAO, 1998. Asia-Pacific Forestry Towards 2010: Executive Summary, the Asia-Pacific Forestry Sector Outlook Study. Food and Agricultural Organization of the United Nations, Rome.
Franklin, N., Bastoni, Sriyanto, Dwiatmo, S., Manansang, J., Tilson, R., 1999. Last of the Indonesian tigers: a cause for optimism. In: Seidensticker, J., Christie, S., Jackson, P. (Eds.), Riding the Tiger: Tiger Conservation in Human-dominated Landscapes. Cambridge University Press, Cambridge, pp. 130-147.

FWI/GFW, 2002. The State of the Forest: Indonesia. Forest Watch Indonesia and Global Forest Watch USA, Bogor, Indonesia and Washington, DC.

Godoy, R., Bennett, C., 1989. Diversification among coffee smallholders in the Highlands of South Sumatra, Indonesia. Human Ecol. 16, 397.

Groom, M., Jensen, D.B., Knight, R.L., Gatewood, S., Mills, L., Boyd-Heger, D., Soulé, M.E., 1999. Buffer zones: benefits and dangers of compatible stewardship. In: Soulé, M.E., Terborgh, J. (Eds.), Continental Conservation: Scientific Foundations of Regional Reserve Networks. Island Press, Covelo, CA, pp. 171-197.

Hardjono, J.M., 1977. Transmigration in Indonesia. Oxford University Press, Kuala Lumpur, Malaysia.

Harris, L.D., Silva-Lopez, G., 1992. Forest fragmentation and the conservation of biological diversity. In: Fiedler, P.L., Jain, S.K. (Eds.), Conservation Biology: The Theory and Practice of Nature Conservation Preservation and Management. Chapman \& Hall, New York.

Helalsiddiqui, A.S.M., 1998. Present status of wildlife, human casualties by tiger, and wildlife conservation in the Sundarbans of Bangladesh. Tigerpaper 25, 28-32.

Holmes, D., 2002. Indonesia: Where Have all the Forests Gone? Discussion Paper, Environment and Social Development, East Asia and Pacific Region, June 2002. The World Bank, Washington, DC.

Hoogerwerf, A., 1970. Udjung Kulon: The Land of the Last Javan Rhinoceros. E.J. Brill, Leiden.

IUCN, 1998. 1997 United Nations List of Protected Areas. Prepared by WCMC and WCPA. IUCN, Gland, Switzerland.

Janzen, D.H., 1983. No park is an island: increase in interference from outside as park size decreases. OIKOS 41, 402-410.

Johns, N., 1999. Conservation in Brazil's chocolate forest: the unlikely persistence of the traditional cocal agroecosystem. Environ. Manage. 23, 31-47.

Karanth, K.U., Stith, B.M., 1999. Prey depletion as a critical determinant of tiger populations. In: Seidensticker, J., Christie, S., Jackson, P. (Eds.), Riding the Tiger: Tiger Conservation in Human-dominated Landscapes. Cambridge University Press, Cambridge, UK, pp. 104-113.

KMNKLH, 1985. Penelitian Pengembangan buffer zone pelestarian alam Taman Nasional Gunung Leuser: Penanggulangan Gangguan harimau Sumatera. Kantor Menteri Negara Kependudukan dan Lingkungan Hidup, Jakarta.

Kramer, R., Schaik, C.v., Johnson, J. (Eds.), 1997. Last Stand: Protected Areas and the Defense of Tropical Biodiversity. Oxford University Press, New York.

Lair, R., 1997. Gone Astray: The Care and Management of the Asian Elephant in Domesticity. FAO Regional Office for Asia and the Pacific, Bangkong, Thailand.

Lawton, J.H., Bignell, D.E., Bolton, B., Bloemers, G.F., Eggleton, P., Hammond, P.M., Hodda, M., Holt, R.D., Larsen, T.B., 
Mawdsley, N.A., Stork, N.E., Srivastava, D.S., Watt, A.D., 1998. Biodiversity inventories, indicator taxa and effects of habitat modification in tropical forests. Nature 391, 72-76.

Levine, J.S., Bobbe, T., Ray, N., Witt, R.G., Singh, A., 1999. Wildland Fires and the Environment: A Global Synthesis. UNEP.

MacAndrews, C., 1998. Improving the management of Indonesia's national parks: lessons from two case studies. Bull. Indonesian Econ. Stud. 34, 121-137.

MacKinnon, J., MacKinnon, C., Child, G., Thorsell, J., 1986. Managing Protected Areas in the Tropics. International Union for the Conservation of Natural Resources, Gland, Switzerland.

McDougal, C., 1987. The man-eating tiger in geographic and historical perspective. In: Tilson, R.L., Seal, U.S. (Eds.), Tigers of the World: The Biology, Biopolitics, Management, and Conservation of an Endangered Species. Noyes Publications, Park Ridge, NJ, pp. 435-448.

McDougal, C., 1999. Tiger attacks on people in Nepal. Cat News $30,9-10$.

McKay, G.M., 1973. Behavior and Ecology of the Asiatic Elephant in Southeastern Ceylon. Smithsonian Institution Press, Washington, DC.

McNeely, J.A., 1978. Management of elephants in Southeast Asia. In: McNeely, J. (Ed.), Wildlife Management in Southeast Asia. Biotrop, Bogor, Indonesia, pp. 219-225.

Michon, G., de Foresta, H., 1990. Complex agroforestry systems and the conservation of biological diversity in harmony with nature. In: Proceedings of the International Conference on Tropical Biodiversity, Kuala Lumpur, Malaysia, p. 457.

Ministry of Forestry, 1995. Way Kambas National Park Management Plan: 1994-2019. Directorate General of Forest Protection and Nature Conservation, Ministry of Forestry, Bogor, Indonesia.

MSPE, 1992. Draft Report of the Indonesian Country Study on Biological Diversity. Ministry of State for Population and Environment, Jakarta, Indonesia.

Nair, P.K.R., 1991. State-of-the-art agroforestry systems. For. Ecol. Manage. 45, 5.

Norchi, D., Bolze, D., 1995. Saving the Tiger: A Conservation Strategy. Wildlife Conservation Society, New York.

Noss, R.F., Dinerstein, E., Gilbert, B., Gilpin, M., Miller, B.J., Terborgh, J., Trombulak, S., 1999. Core areas: where nature reigns. In: Soulé M.E., Terborgh, J. (Eds.), Continental Conservation: Scientific Foundations of Regional Reserve Networks. Island Press, Covelo, CA, pp. 99-128.

Nowell, K., Jackson, P. (Eds.), 1996. Wild Cats: Status Survey and Conservation Action Plan. IUCN, Gland, Switzerland.

Nyhus, P., Sumianto, Tilson, R., 1999. The tiger human dimension in southeast Sumatra, Indonesia. In: Seidensticker, J., Christie, S., Jackson, P. (Eds.), Riding the Tiger: Tiger Conservation in Human-dominated Landscapes. Cambridge University Press, Cambridge, pp. 144-145.

Nyhus, P., Sumianto, Tilson, R., 2000. Crop-raiding elephants and conservation implications at Way Kambas National Park, Sumatra, Indonesia. Oryx 34, 262-275.

Nyhus, P.J., Fisher, H., Madden, F., Osofsky, S., 2003. Taking the bite out of wildlife damage: the challenges of wildlife compensation schemes. Conserv. Practice 4, 37-40.
Nyhus, P.J., Tilson, R., 2004. Characterizing tiger-human conflict in Sumatra, Indonesia: Implications for conservation. Oryx 38, 68-74.

Padoch, C., Peters, C., 1993. Managed forest gardens in West Kalimantan, Indonesia. In: Potter, C.S., Cohen, J.I., Janczewski, D. (Eds.), Persectives on Biodiversity: Case Studies of Genetic Resource Conservation and Development. American Association for the Advancement of Science Press, Washington, DC, pp. 167-176.

Pagiola, S., 2001. Deforestation and Land Use Changes Induced by the East Asian Economic Crisis. East Asian Environment and Social Development Unit (EASES) Discussion Paper.

Pimentel, D., Stachow, U., Takacs, D.A., Brubaker, H.W., Dumas, A.R., Meaney, J.J., O’Neil, J.A.S., Onsi, D.E., Corzilius, D.B., 1992. Conserving biological diversity in agricultural/forestry systems. BioScience 4, 354-362.

Potter, L., Lee, J., 1998. Tree Planting in Indonesia: Trends, Impacts, and Directions. Center for International Forestry Research, Bogor, Indonesia.

Saberwal, V.K., Gibbs, J.P., Chellam, R., Johnsingh, A.J.T., 1995. Lion-human conflict in the Gir forest, India. In: Ehrenfeld, D. (Ed.), Readings from Conservation Biology: The Social Dimension-Ethics, Policy, Law, Management, Development, Economics, Education. Society for Conservation Biology and Blackwell Science, Boston.

Salafsky, N., 1993. Mammalian use of a buffer zone agroforestry system bordering Gunung Palung National Park, West Kalimantan, Indonesia. Conserv. Biol. 7, 928-933.

Santiapillai, C., 1990. Why do elephants raid crops in Sumatra? The ASEAN Workshop on Wildlife Research and Management and the Meeting on Establishment of ASEAN Wildlife Society. Directorate General of Forest Protection and Nature Conservation, Ministry of Forestry, Bogor, Indonesia.

Santiapillai, C., Jackson, P., 1990. The Asian Elephant: An Action Plan for its Conservation. IUCN/SSC Asian Elephant Specialist Group.

Santiapillai, C., Ramono, W.S., 1985. On the Status of the Tiger (Panthera tigris sumatrae Pocock, 1829) in Sumatra. WWF/IUCN.

Santiapillai, C., Ramono, W.S., 1993. Why do elephants raid crops in Sumatra. Gajah 11, 55-58.

Santiapillai, C., Suprahman, H., 1986. The Ecology of the Elephant (Elephas maximus L.) in the Way Kambas Game Reserve, Sumatra. WWF/IUCN, Bogor.

Sayer, J., 1991. Rainforest buffer zones. Guidelines for Protected Area Managers. IUCN, Gland, Switzerland.

SBKDSA-Jambi, 1997. Harimau Sumatera (Panthera tigris sumatrae), Eksistensi dan permasalahannya di Propinsi Jambi. Sub Balai Konservasi Sumber Daya Alam Jambi, Jambi.

Seidensticker, J., 1984. Managing Elephant Depredations in Agricultural and Forestry Projects. The World Bank, Washington, DC.

Seidensticker, J., 1986. Large carnivores and the consequences of habitat insularization: ecology and conservation of tigers in Indonesia and Bangladesh. In: Miller, S.D., Everett, D.D. (Eds.), Cats of the World: Biology, Conservation, and Management. National Wildlife Federation, Washington, DC, pp. 1-41. 
Seidensticker, J., 1987. Bearing witness: observations on the extinction of Panthera tigris balica and Panthera tigris sondaica. In: Tilson, R.L., Seal, U.S. (Eds.), Tigers of the World: The Biology, Biopolitics, Management, and Conservation of an Endangered Species. Noyes Publications, Park Ridge, NJ, pp. 1-8.

Seidensticker, J., 1997. Saving the tiger. Wildl. Soc. Bull. 25, 617.

Seidensticker, J., Christie, S., Jackson, P. (Eds.), 1999. Riding the Tiger: Tiger Conservation in Human-dominated Landscapes. Cambridge University Press, Cambridge, UK.

Shafer, C.L., 1990. Nature Reserves: Island Theory and Conservation Practice. Smithsonian Institution Press, Washington, DC.

Siebert, S.F., 1989. The dilemma of a dwindling resource: Rattan in Kerinci, Sumatra. Principles 33, 79.

Sinaga, D.W., 1995. Beberapa alternatif dan usulan rencana kegiatan perlindungan dan pengamanan populasi dan habitat satwa harimau Sumatera (Panthera tigris sumatrae) di wilayah Sumatera ditinjau dari aspek pengamanan flora dan fauna, Bogor.

Soulé, M.E., Terborgh, J. (Eds.), 1999. Continental Conservation: Scientific Foundations of Regional Reserve Networks. Island Press, Covelo, CA.

STP, 1997. Sumatran Tiger Project Report. Sumatran Tiger Project, Minneapolis, MN.

STP, 1998. Sumatran Tiger Project Quarterly Report. Sumatran Tiger Project, Apple Valley, MN.

Sukumar, R., 1989. The Asian Elephant: Ecology and Management. Cambridge University Press, Cambridge.

Sukumar, R., Gadgil, M., 1988. Male-female differences in foraging on crops by Asian elephants. Anim. Behav. 36, 12331235.

Sunderlin, W.D., Resosudarmo, I.A.P., 1996. Rates and Causes of Deforestation in Indonesia: Toward a Resolution of Ambiguities. Center for International Forestry Research (CIFOR), Bogor.

Thiollay, J.M., 1995. The role of traditional agroforests in the conservation of rain forest bird diversity in Sumatra. Conserv. Biol. 9, 335.

Tilson, R., Defu, H., Muntifering, J., Nyhus, P.J., 2004. Dramatic decline of wild South China tigers: Field survey of priority tiger reserves. Oryx 38, 40-47.

Tilson, R., Franklin, N., Nyhus, P., Bastoni, Sriyanto, Siswomartono, D., Manansang, J., 1996. In situ conservation of the Sumatran Tiger in Indonesia. Int. Zoo News 43, 316324.

Tilson, R., Nyhus, P., 1998. Keeping problem tigers from becoming a problem species. Conserv. Biol. 12, 261-262.

Tilson, R., Nyhus, P., Franklin, N., 2001. Tiger restoration in Asia: ecological theory vs. sociological reality. In: Maehr, D.S., Noss, R.F., Larkin, J.L. (Eds.), Large Mammal Restoration: Ecological and Sociological Challenges in the 21st Century. Island Press, Washington, DC, pp. 277-291.

Tilson, R., Siswomartono, D., Manansang, J., Brady, G., Armstrong, D., Traylor-Holzer, K., Byers, A., Christie, P., Salfifi, A., Tumbelaka, L., Christie, S., Richardson, D., Reddy, S., Franklin, N., Nyhus, P., 1997. International co-operative efforts to save the Sumatran tiger Panthera tigris sumatrae. Int. Zoo Yearbook 35, 129-138.

Tilson, R., Soemarna, K., Ramono, W., Sukumar, R., Seal, U., Traylor-Holzer, K., Santiapillai, C. (Eds.), 1994a. Asian Elephant in Sumatra: Population and Habitat Viability Analysis Report. IUCN/SSC Conservation Breeding Specialist Group, Apple Valley, MN.

Tilson, R.L., Soemarna, K., Ramono, W., Lusli, S., TraylorHolzer, K., Seal, U.S., 1994b. Sumatran Tiger Population and Habitat Viability Analysis Report. IUCN/SSC Captive Breeding Specialist Group, Apple Valley, MN.

Van Schaik, C.P., Terborgh, J., 1993. Production forests and protected forests: the potential for mutualism in the tropics. Trop. Biodiversity 1, 183.

Vandermeer, J., Noordwijk, M.v., Anderson, J., Ong, C., 1998. Global change and multi-species agroecosystems: concepts and issues. Agric. Syst. Environ. 67, 1-22.

Whitten, A.J., Damanik, S.J., Anwar, J., Hisyam, N., 1987. The Ecology of Sumatra. Gajah Mada University Press, Yogyakarta, Indonesia.

Wilcox, B.A., Murphy, D.D., 1985. Conservation strategy: the effect of fragmentation on extinction. Am. Nat. 125, 879887.

Wojtkowski, P.A., 1993. Toward an understanding of tropical home gardens. Agroforest. Syst. 24, 215.

Woodroffe, R., Ginsberg, J.R., 1998. Edge effects and the extinction of populations inside protected areas. Science 280, 2126-2128.

WRI, 2000. World Resources 2000-2001: People and Ecosystems: The Fraying Web of Life. World Resources Institute, Washington, DC. 